\title{
Erratum to: Microwave-assisted, water-mediated Michael addition for synthesis of kojic acid derivatives
}

\author{
Pravin R. Likhar ${ }^{1}$ - G. Narshimha $\operatorname{Reddy}^{1} \cdot$ M. Ramana $\operatorname{Reddy}^{1}$
}

\section{Erratum to: Res Chem Intermed \\ DOI 10.1007/s11164-015-2419-1}

In the original publication of the article, the corresponding author information was incorrectly published. The name of the corresponding author should be Pravin R. Likhar, instead of G. Narshimha Reddy.

The online version of the original article can be found under doi:10.1007/s11164-015-2419-1.

Pravin R. Likhar

plikhar@iict.res.in

G. Narshimha Reddy

gajjalanarsireddy@gmail.com

1 Organometallic Group, Inorganic and Physical Chemistry Division, CSIR-Indian Institute of Chemical Technology, Hyderabad 500007, India 